\title{
Bacteriological investigation of pyometra of Black Bengal goats obtained at slaughter
}

\author{
ABMJ Uddin, M Nooruzzaman, T Akter, MAHNA Khan and MM Hossain* \\ Department of Pathology, Faculty of Veterinary Science, Bangladesh Agricultural \\ University, Mymensingh-2202, Bangladesh
}

\begin{abstract}
Nine uteri of Black Bengal goats (Capra hircus) affected with pyometra were collected from three slaughterhouses at Kishoreganj district of Bangladesh. Both horns of each uterus were washed with phosphate buffered saline for isolation and identification of bacteria and its load. The bacterial loads in the uterus were high, ranging between $1 \times$ $10^{7}$ and $2.8 \times 10^{7}$. Six different bacterial species were identified and confirmed by Polymerase Chain Reaction (PCR). There were five Escherichia coli, six Streptococcus sp., five Staphylococcus sp, one Salmonella sp., one Pasteurella sp. and one Bacillus sp. All had mixed infections containing two or three types of bacterial pathogens. Further studies are needed for the virulence determination and antibiogram profiles. (Bangl. vet. 2019. Vol. 36, No. 1 - 2, 1 - 7)
\end{abstract}

\section{Introduction}

Genital infections in female domestic ruminants are often caused by opportunistic secondary invaders, especially Escherichia coli, which has frequently been isolated in ewes (Manes et al., 2010; Martins et al., 2009; Sargison et al., 2007), goats (Ababneh and Degefa, 2006) and cows (Sheldon et al., 2008). Under stress conditions, these opportunist bacteria may cause genital infection that can lead to reproductive failure in ruminants (Levinson and Jawetz, 1994; Shallali et al., 2001).

Uterus normally remain free from bacterial infection, but can get contaminated during mating and at parturition. Various reproductive disorders and diseases have been reported in Black Bengal goats, which often limit the reproductive performance (Ahmed, 1993; Bhuiyan et al., 1988; Rahman et al., 2010; Roy et al., 2001). Uterine infections, caused by variety of microorganisms, need more attention towards treatment and control. The present study was planned to detect bacteria in uteri of Black Bengal goats at slaughterhouse.

\section{Materials and Methods}

\section{Sample collection and processing}

A total of 256 female genitalia of Black Bengal goats were collected from three slaughterhouses at Kishoreganj district of Bangladesh during October 2016 to

\footnotetext{
*Corresponding author:- E-mail: mmhossain04@yahoo.com.au
}

DOI: https://doi.org/10.3329/bvet.v36i1-2.55744 
December 2018. Those with pyometra were transported to the laboratory under cool conditions. Aseptically, $2 \mathrm{ml}$ of sterile phosphate buffered saline (PBS) was used to wash each horn of each uterus. The wash was collected using sterile syringe.

\section{Quantification of bacterial loads in the uterus}

The uterine washes were diluted 10-fold and three of such dilutions were streaked over nutrient agar plates (three plates per dilution) and incubated at $37^{\circ} \mathrm{C}$ for $24 \mathrm{~h}$. The number of colonies in the individual plates were counted to calculate the bacterial load, expressed as colony forming units (CFU)/ml.

\section{Isolation and identification of the bacteria}

Samples were pre-enriched in nutrient broth at $37^{\circ} \mathrm{C}$ for 24 hours. For pure culture, small amount of pre-enriched culture was placed on an inoculation loop and streaked across the surface of nutrient agar plates. Selected single colonies from nutrient agar plates were streaked into selective agar media: blood (HiMedia, India), MacConkey (HiMedia, India), eosin methylene blue (EMB) (HiMedia, India), Salmonella-Shigella (SS) (HiMedia, India), xylose lysine deoxycholate (XLD) (HiMedia, India) and incubated at $37^{\circ} \mathrm{C}$ for $24-48$ hours. The colony morphology was recorded. Bacteria from selected colonies were stained with Gram's stain. Sugar fermentation test, methyl-red (MR) test, Voges-Proskauer (VP) test, catalase test, oxidase test was done for bacterial identification as described by Cowan (1985).

\section{Molecular detection of bacterial species by PCR}

The molecular identity of Escherichia coli, Salmonella sp. and Pasteurella sp. was confirmed by PCR. Bacterial DNA was extracted using DNA extraction kit (Promega, USA) according to the manufacturer's instructions. The list of primers used in PCR is shown in Table 1. PCR amplification was performed in a final volume of $25 \mu 1$ containing $12.5 \mu \mathrm{l}$ ready master mix (DreamTaq DNA Polymerases, Thermo Scientific, USA), $2 \mu \mathrm{l}(50 \mathrm{ng} / \mu \mathrm{l})$ of DNA template, $2 \mu \mathrm{l}(100 \mathrm{mM})$ of each primer, and $8.5 \mu \mathrm{l}$ nuclease-free water. The thermal profile was initial denaturation at $94^{\circ} \mathrm{C}$ for $5 \mathrm{~min}$, followed by 35 cycles each consisting of denaturation at $94^{\circ} \mathrm{C}$ for $30 \mathrm{sec}$, annealing at $60^{\circ} \mathrm{C}$ for $30 \mathrm{sec}$, and extension at $72^{\circ} \mathrm{C}$ for $50 \mathrm{sec}$, and final extension at $72^{\circ} \mathrm{C}$ for $10 \mathrm{~min}$. The PCR amplified products were separated by electrophoresis on $1.5 \%$ agarose gel and visualized under UV light in a gel documentation system.

Table 1: List of primers used in the molecular detection of bacterial species by PCR

\begin{tabular}{|c|c|c|c|c|c|}
\hline Pathogens & Genes & $\begin{array}{c}\text { Primer } \\
\text { name }\end{array}$ & Sequence $\left(5^{\prime}-3^{\prime}\right)$ & $\begin{array}{l}\text { Amplicon } \\
\text { Size (bp) }\end{array}$ & Reference \\
\hline $\begin{array}{l}\text { Escherichia } \\
\text { coli }\end{array}$ & yjaA & $\begin{array}{l}\text { EC_YjaA.1 } \\
\text { EC_YjaA.2 }\end{array}$ & $\begin{array}{l}\text { TGAAGTGTCAGGAGACGCTG } \\
\text { ATGGAGATGCGTTCCTCAAC }\end{array}$ & 211 & $\begin{array}{l}\text { Clermont et } \\
\text { al., } 2000\end{array}$ \\
\hline $\begin{array}{l}\text { Salmonella } \\
\text { sp. }\end{array}$ & $i n v A$ & $\begin{array}{l}\text { invA F } \\
\text { invA R }\end{array}$ & $\begin{array}{l}\text { GTGAAATTATCGCGTTCGGGCAA } \\
\text { TCATCGCACCGTCAAAGGAACC }\end{array}$ & 284 & $\begin{array}{l}\text { Rahn et. al., } \\
1992\end{array}$ \\
\hline $\begin{array}{l}\text { Pasteurella } \\
\text { sp. }\end{array}$ & $\begin{array}{c}16 S \\
r R N A\end{array}$ & $\begin{array}{c}\text { KMT1T7 } \\
\text { KMT1SRp6 }\end{array}$ & $\begin{array}{c}\text { GCTGTAAACGAACTCGCCAC } \\
\text { ATCCGCTATTTACCCAGTGG }\end{array}$ & 460 & $\begin{array}{l}\text { Townsend } \\
\text { et al., } 2001\end{array}$ \\
\hline
\end{tabular}




\section{Statistical analysis}

Graphs were prepared using GraphPad Prism 5.0 software. To visualize the prevalence of co-occurrences of bacterial pathogens, an UpSetR plot was prepared using an online platform (https://gehlenborglab.shinyapps.io/upsetr/).

\section{Results and Discussion}

\section{Detection of bacterial load}

The bacterial load in the uterus of Black Bengal goats with pyometra was quantified in nine goats. The loads ranged from $1 \times 10^{7}$ to $2.8 \times 10^{7}$ (Fig. 1). The loads in the right horn of B/1, B/4, B/7, B/9, B/11, B/12 samples were $2.7 \times 10^{7}, 2.4 \times 10^{7}, 1 \times 10^{7}, 2.7 \times$ $10^{7}, 2.6 \times 10^{7}$ and $2.6 \times 10^{7}$, respectively while in left horns were $2.8 \times 10^{7}, 2.4 \times 10^{7}, 1.3$ $\times 10^{7}, 2.2 \times 10^{7}, 2.4 \times 10^{7}$ and $2.7 \times 10^{7}$, respectively. Bacterial loads in the right horn of $\mathrm{K} / 20$ and $\mathrm{K} / 24$ samples were $2.8 \times 10^{7}$ and $2.4 \times 10^{7}$, while in left horns were $2.6 \times 10^{7}$ and $1.7 \times 10^{7}$, respectively. Bacterial loads in the right horn of $\mathrm{Bt} / 30$ sample were $2.4 \times$ $10^{7}$, while in left horn was $2.1 \times 10^{7}$.

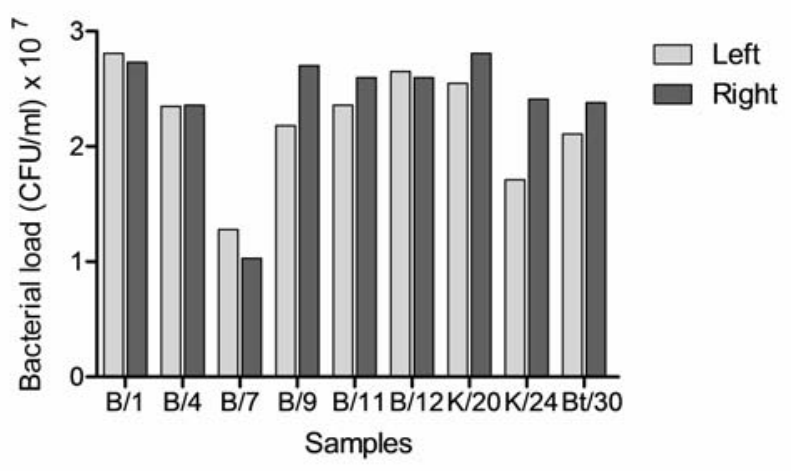

Fig. 1: Bacterial load in uteri of Black Bengal goats collected from slaughterhouses, and affected by pyometra.

\section{Isolation and identification of bacteria}

Out of 256 uteri, 56 (21.9\%) showed pathological changes including nine cases $(2 \%)$ of pyometra. Six bacterial species were identified based on colony characteristics, Gram's stain and biochemical tests.

All bacterial isolates were further characterized using biochemical tests (Table 2). The E. coli fermented all five-basic sugars with production of both acid and gas, catalase, indole and MR positive but VP negative. Both Staphylococcus and Bacillus isolates fermented all five-basic sugar with formation of acid, catalase, indole and MR positive but VP negative. The Pasteurella isolate fermented dulcitol, sucrose and mannitol with production of acid and showed catalase, indole and VP positive but MR negative. The Salmonella isolate fermented dulcitol, maltose and mannose with the production of acid and was MR positive. The Streptococcus fermented all five basic sugars except mannose with acid production and was MR positive. 
Table 2: Biochemical characteristics of the isolated bacteria from uterus of Black Bengal goats

\begin{tabular}{|c|c|c|c|c|c|c|c|c|c|}
\hline \multicolumn{5}{|c|}{ Sugar fermentation } & \multirow[t]{2}{*}{ Catalase } & \multirow[t]{2}{*}{ Indole } & \multirow[t]{2}{*}{ MR } & \multirow[t]{2}{*}{ VP } & \multirow[t]{2}{*}{ Bacterial isolates } \\
\hline $\mathrm{D}$ & ML & S & $\mathrm{L}$ & $\mathrm{MN}$ & & & & & \\
\hline $\mathrm{AG}$ & AG & $\mathrm{AG}$ & $\mathrm{AG}$ & AG & + & + & + & - & Escherichia coli \\
\hline A & A & A & A & A & + & + & + & - & Staphylococcus sp. \\
\hline A & A & A & A & A & + & + & + & - & Bacillus sp. \\
\hline A & - & A & - & A & + & + & - & + & Pasteurella sp. \\
\hline A & A & - & - & A & - & - & + & - & Salmonella sp. \\
\hline A & A & A & A & - & - & - & + & - & Streptococcus sp. \\
\hline
\end{tabular}

Note: $\mathrm{D}=$ Dulcitol, $\mathrm{ML}=$ Maltose, $\mathrm{S}=$ Sucrose, $\mathrm{L}=$ Lactose, $\mathrm{MN}=$ Mannitol, $\mathrm{MR}=$ Methyl Red, $\mathrm{VP}=$ Voges-Proskauer, A = Acid, AG = Acid and Gas, ' +' = positive, ' -' = negative.

The PCR method successfully amplified the target DNA and confirmed the identity of five isolates of E. coli, one of Salmonella sp. and one of Pasteurella sp.

\section{Prevalence of different bacteria in pyometra affected uterus of Black Bengal goats}

A total of 19 bacteria belonging to six genera were identified (Table 3). There were five E. coli, six Streptococcus sp., five Staphylococcus sp., one Salmonella sp, one Pasteurella sp. and one Bacillus sp.

Table 3: Types and frequency of bacteria isolated from uteri of Black Bengal goats with pyometra

\begin{tabular}{l|c|c}
\hline \multicolumn{1}{c}{ Types of bacteria } & Number & $\%(\mathrm{n}=18)$ \\
\hline Escherichia coli & 5 & $27.8 \%$ \\
Streptococcus sp. & 6 & $33.3 \%$ \\
Staphylococcus sp. & 5 & $27.8 \%$ \\
Salmonella sp. & 1 & $5.6 \%$ \\
Pasteurella sp. & 1 & $5.6 \%$ \\
Bacillus sp. & 1 & $5.6 \%$ \\
\hline Total & $\mathbf{1 9}$ & \\
\hline
\end{tabular}

Two or three bacterial pathogens were in all nine uteri (Fig. 2). E. coli and Streptococcus sp. were in three uteri. E. coli, Streptococcus sp. and Staphylococcus sp. were in one uterus.

Six different types of bacteria were in uteri with pyometra in Black Bengal goats. Vaginal bacteria get access into the uterus during the peripartum period leading to metritis and endometritis (Levinson and Jawetz, 1994). It is important to identify causal agents with a view to providing remedies. 


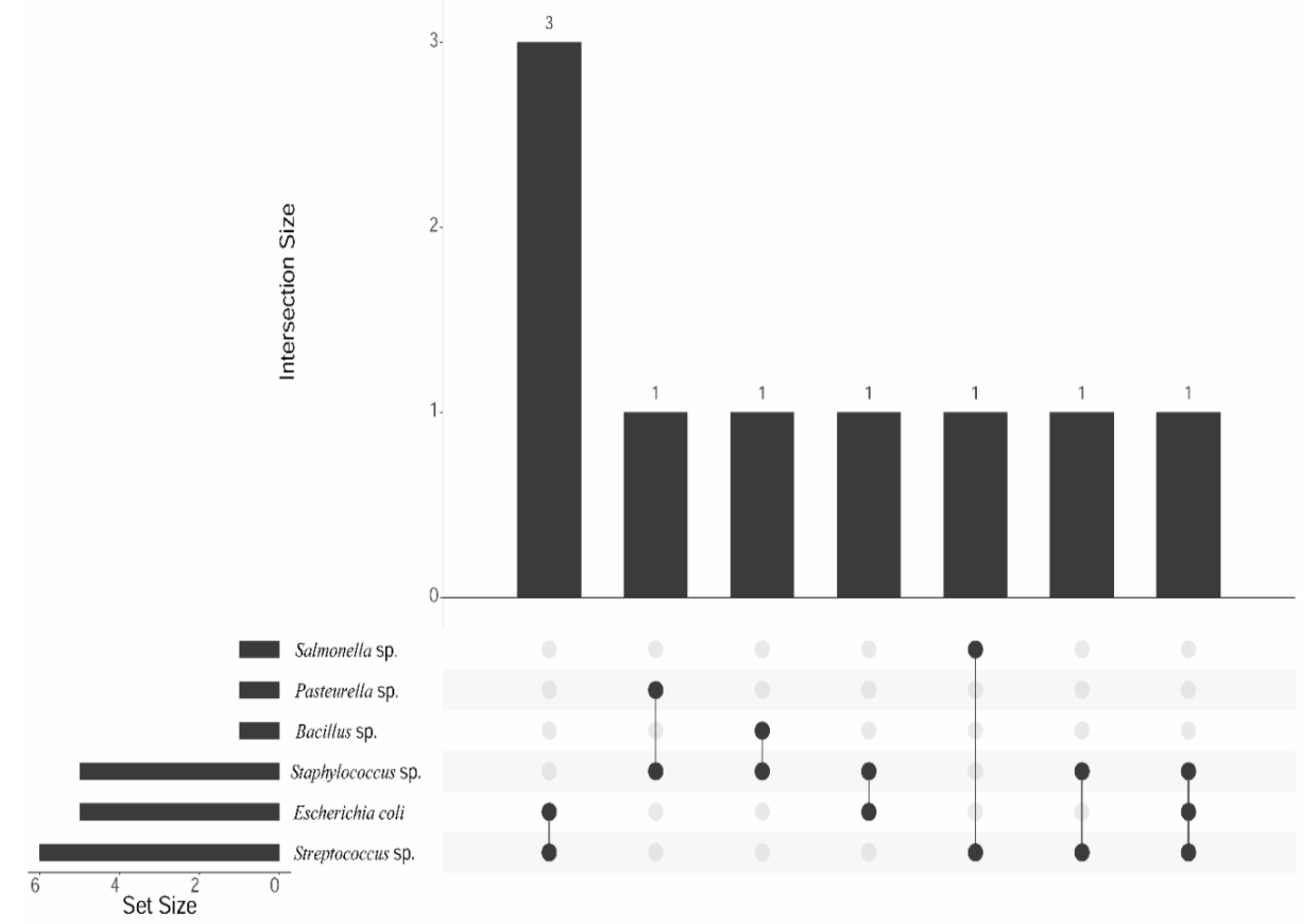

Fig. 2: An Upsets plot showing co-presence of different bacterial species in the pyometra affected uterus of Black Bengal goats.

The development of uterine disease depends on the immune response of the animals, as well as the species and number of bacteria. Clinical signs of uterine infection vary (Azawi, 2008). A very high bacterial load and at least six bacterial species were detected. The species are well known for their pyogenic properties. Other than the ubiquitous E. coli, three different species of Staphylococcus sp., S. aureus, S. intermedius and S. epidermidis were reported as major pathogens in the uterus of goats in Pakistan (Rind and Shaikh, 2000). However, further characterization of the bacteria is required to confirm their species and genetic constitution.

The pathogenic organisms may lead to sterility or infertility. All the tested uteri had mixed infection with two or three pathogens. A similar study on uteri of slaughtered goats in Pakistan detected very high $(80 \%)$ rate of bacterial infections and 11 bacterial species were isolated (Rind and Shaikh, 2000). The present findings corroborate the observations of Tadayon et al. (1980) and Talan et al. (1989) who detected 2 - 4 species in a single wound sample. Malik et al. (1987) studied 395 mucus samples from infertile cattle and recorded mixed infection. A similar trend was encountered by Tadayon et al. (1980) who recorded $29.1 \%$ mixed infections that contained 2 - 4 different species. Malik et al. (1987) detected mixed infections from $64 \%$ of uterine mucus samples of infertile cattle. 


\section{Conclusions}

A high bacterial load in the uteri of Black Bengal goats were detected in slaughterhouse materials. At least six different bacterial species were involved in pyometra, which occurred as co-infection of two or three pathogens. Presence of mixed bacterial species is common in the uterine infection and deserves further study with antimicrobial susceptibility.

\section{Acknowledgements}

The financial support by Bangladesh Agricultural University Research System (BAURES) is appreciated.

\section{References}

Ababneh MM, Degefa T 2006: Bacteriological findings and hormonal profiles in the postpartum Balady goats. Reproduction in Domestic Animals 41 12-16.

Ahmed JU 1993: Incidence of gynaeco-obstetrical disorders in Black Bengal goats. Bangladesh Agricultural University Research Progress 7 499-505.

Azawi OI 2008: Postpartum uterine infection in cattle. Animal Reproduction Science 105 187-208.

Bhuiyan MJ, Hossain MI, Moslehuddin, Shahasuddin M 1988: Female reproductive disorders in Black Bengal goats of Bangladesh. Bangladesh Veterinarian 15 49-50.

Clermont O, Bonacorsi S, Bingen E 2000: Rapid and simple determination of the Escherichia coli phylogenetic group. Applied and Environmental Microbiology 66 4555-4558.

Cowan ST 1985: Cowan and Steel's Manual for Identification of Medical Bacteria. 2nd edn, Cambridge University Press, Cambridge, London.

Levinson WE, Jawetz E 1994: Medical Microbiology and Immunology. Third edition. Prentice Hall Int. Inc., Englewood Cliffs, New Jersey, USA. pp. 20-23.

Malik SZ, Chaudhry MA, Nazir A, Rehman N 1987: Different antibiotics in the treatment of uterine infections in repeat breeding cows in Faisalabad. Pakistan Veterinary Journal 7 60-62.

Manes J, Fiorentino MA, Kaiser G, Hozbor F, Alberio R, Sanchez E, Paolicchi F 2010: Changes in the aerobic vaginal flora after treatment with different intravaginal devices in ewes. Small Ruminant Research 94 201-204.

Martins G, Figueira L, Penna B, Brandão F, Varges R, Vasconcelos C, Lilenbaum W 2009: Prevalence and antimicrobial susceptibility of vaginal bacteria from ewes treated with progestin-impregnated intravaginal sponges. Small Ruminant Research 81 182-184.

Rahman MH, Chowdhury EH, Saha SS, Islam A, Alam MGS 2010: Abattoir study of reproductive diseases in goats. Bangladesh Veterinarian 25 88-91. 
Rahn K, De Grandis SA, Clarke RC, McEwen SA, Galán JE, Ginocchio C, Curtiss III R, Gyles CL 1992: Amplification of an invA gene sequence of Salmonella typhimurium by polymerase chain reaction as a specific method of detection of Salmonella. Molecular and Cellular Probes 6 271-279.

Rind R, Shaikh, SN 2000: Bacteriological studies on the uteri of slaughtered goats. Pakistan Journal of Biological Sciences 3 1944-1947.

Roy BJ, Hossain MM, Chowdhury EH, Biswas PK, Hossain AKMA, Saha S 2001: Etiopathological investigation of systemic diseases in slaughtered Black Bengal goats. Bangladesh Veterinary Journal 35 67-73.

Sargison ND, Howie F, Mearns R, Penny CD, Foster G 2007: Shiga toxin-producing Escherichia coli as a perennial cause of abortion in a closed flock of Suffolk ewes. Veterinary Record 160 875-876.

Shallali AA, Hussein AM, Salih MM, Dafalla EA 2001: A preliminary report on bacteria isolated from the female genital tract of Sudanese sheep and goats. The Sudan Journal of Veterinary Research 17 55-63.

Sheldon IM, Williams EJ, Miller AN, Nash DM, Herath S 2008: Uterine diseases in cattle after parturition. Veterinary Journal 176 115-121.

Tadayon RA, Cheema RH, Muhammed SI 1980: Microorganisms associated with abscesses of sheep and goats in the South of Iran. American Journal of Veterinary Research $\mathbf{4 1}$ 798-802.

Talan DA, Staatz D, Staatz A, Goldstein EJ, Singer K, Overturf GD 1989: Staphylococcus intermedius in canine gingiva and canine-inflicted human wound infections: laboratory characterization of a newly recognized zoonotic pathogen. Journal of Clinical Microbiology 27 78-81.

Townsend KM, Boyce JD, Chung JY, Frost AJ, Adler B 2001: Genetic organization of Pasteurella multocida cap Loci and development of a multiplex capsular PCR typing system. Journal of Clinical Microbiology 39 924-929. 